УДК $347.9 ; 340.1$

DOI https://doi.org/10.32837/apdp.v0i92.3259

О. В. Колісник

\title{
ПРЕЦЕДЕНТ ТЛУМАЧЕННЯ У ПРАКТИЦІ ЦИВІЛЬНОГО СУДОЧИНСТВА
}

Постановка проблеми. Принцип правової визначеності як складовий елемент верховенства права містить вимогу щодо однозначного тлумачення правових норм задля забезпечення їх однакового застосування судами при вирішенні цивільних, господарських та адміністративних справ. Саме тому не вщухають дискусії з приводу доречності запровадження та використання в українській правовій доктрині терміна «прецедент» у контексті визнання його джерелом права, особливо на тлі суттєвих та кардинальних змін в системі судоустрою України, які відбулися наприкінці 2017 р. Надання Верховному Суду статусу найвищого суду в системі судоустрою України, із покладенням на нього функцій із забезпечення сталості та єдності судової практики, стало поштовхом до активізації наукових публікацій щодо передумов та можливостей впровадження у національну правову систему та судову практику елементів прецедентного права. У науковому середовищі розгорнулися дебати щодо співвідношення категорій «судовий прецедент», «прецедент тлумачення», «усталена судова практика», а також щодо коректності та доцільності використання кожного з них.

Аналіз останніх досліджень і публікацій. Дослідженню питань існування прецеденту в Україні, доцільності запровадження додаткового джерела права у вигляді судового прецеденту присвячено роботи Ю.Ю. Рябченка, О.А. Любчика, О.С. Кізлової. Питання судової правотворчості досліджували такі вчені, як Д.Д. Луспеник, А.А. Марченко, Л.Г. Лічман, І.П. Зеленко. Вивченню проблем єдності судової практики у контексті формування єдиної правозастосовчої практики та забезпечення принципу правової визначеності значної уваги у своїх роботах приділяють В.В. Комаров, Т.А. Цувіна, О.І. Попов.

Мета і завдання. Метою статті є з'ясування доцільності та допустимості використання термінів "судовий прецедент», «прецедент тлумачення», «усталена судова практика» в умовах системи судоустрою України та процесуального законодавства України, виявлення особливостей прецеденту в національному цивільному судочинстві.

Виклад основного матеріалу. Чи має право на існування як окремої категорії термін «прецедент тлумачення», чи все ж він є різновидом судового прецеденту? Що таке «усталена судова практика» - сукупність судових прецедентів чи прецедентів тлумачення, ухвалених у певній сфері правового регулювання? Чи може бути змінена так звана «усталена судова практика»? Іншими словами, одним із ключових моментів наукової дискусії є з'ясування співвідношення між судовою правотворчістю та тлумаченням правових норм.

Безумовно, єдиним органом законодавчої влади в Україні є Верховна Рада України. Завдання ж судової влади зводиться до здійснення правосуддя, під 
час якого відбувається застосування правових норм до конкретних правовідносин і ухвалення рішення. Однак багатоманіття життєвих ситуацій часто ставить нові завдання перед законодавцем, який не завжди встигає вчасно та динамічно відреагувати на це відповідними змінами до законодавства. Водночас одним із завдань Верховного Суду є забезпечення єдності судової практики, саме тому у певних випадках Верховний Суд частково перебирає на себе функції «правотворця» до того моменту, доки певні спірні правовідносини не знайдуть правового регулювання на законодавчому рівні. Акти правосуддя у такому разі фактично виступають орієнтиром для законодавця щодо подальших законодавчих змін. Згідно з ч. 10 ст. 10 ЦПК забороняється відмова у розгляді справи з мотивів відсутності, неповноти, нечіткості, суперечності законодавства, що регулює спірні відносини. Із цього приводу Д.Д. Луспеник зазначає, що закон фактично уповноважує суддю на судову правотворчість [1, с. 110]. Отже, заперечувати факт існування в Україні елементів прецедентного права, на наш погляд, неможливо.

Національне цивільне процесуальне законодавство містить згадку про «усталену судову практику» лише у п. 3 ч. 4 ст. 265 ЦПК. А от у ч. 3 ст. 389 та ч. 5 ст. 403 ЦПК йдеться про «єдину правозастосовчу практику». Як бачимо, досліджувана термінологія не знайшла свого широкого поширення та належного закріплення. Із цього приводу О.А. Любчик зауважує, що на сьогодні відсутні причини та об'єктивні підстави (чинне законодавство) стверджувати, що прецедент діє в Україні де-факто; а необхідність офіційного визнання правового прецеденту джерелом права у формальному розумінні сумнівна з точки зору стану її теоретичного підгрунтя, ефективності, традицій правового регулювання в Україні [2, с. 51]. Дещо протилежних висновків з наведенням відповідних аргументів доходить А.А. Марченко, наполягаючи, що судовий прецедент як джерело права не забороняється українським законодавством, проте водночас копіювати властивості судового прецеденту в правовій системі загального права не слід, оскільки в Україні є власні традиції правотворчості та правозастосування і ми сміливо можемо використовувати судовий прецедент як джерело права з «українським обличчям» [3, с. 28].

Підтримуючи позиції вчених щодо фактичного існування елементів прецеденту в українських правових реаліях, варто наголосити, що закріплені у ЦПК та ГПК касаційні фільтри (щодо можливості оскарження судового рішення у касаційному порядку лише у разі відсутності правової позиції Верховного Суду зі спірного питання чи незастосування правової позиції за її наявності судом першої чи апеляційної інстанції тощо) відображає визнання законодавцем прецеденту як невід’ємного елементу правового регулювання правовідносин в Україні. Про це йдеться у ч. 2 ст. 389 ЦПК, яка серед підстав для касаційного оскарження називає неправильне застосування судом норм матеріального права чи порушення норм процесуального права виключно у таких випадках: по-перше, якщо суд апеляційної інстанції в оскаржуваному судовому рішенні застосував норму права без урахування висновку щодо застосування норми права у подібних правовідносинах, викладеного у постанові Верховного Суду, крім випадку наявності постанови Верховного Суду про відступлення від такого висновку; по-друге, якщо скаржник вмотивовано обгрунтував необхідність відступлення від висновку щодо застосування норми права 
у подібних правовідносинах, викладеного у постанові Верховного Суду та застосованого судом апеляційної інстанції в оскаржуваному судовому рішенні; по-третє, якщо взагалі відсутній висновок Верховного Суду з приводу застосування норми права у подібних правовідносинах. Цією нормою законодавець наголосив на особливому значенні правових позицій Верховного Суду щодо тлумачення, роз'яснення та конкретизації правових норм, які регулюють ті чи інші суспільні відносини.

Нагадаємо, що відповідно до ч. 4 ст. 263 ЦПК при виборі і застосуванні норми права до спірних правовідносин суд враховує висновки щодо застосування відповідних норм права, викладені в постановах Верховного Суду. Варто погодитися з О.І. Поповим, який зауважує, що Постанови Верховного Суду, ухвалені за результатами перегляду судових рішень у порядку касації, містять уніфіковані пропозиції щодо правил застосування конкретної норми, чим створюють правозастосовний орієнтир для всієї судової системи при розгляді аналогічних справ, а особливий статус цих судових актів додатково забезпечує превенцію недопущення порушення принципу правової визначеності в межах всієї інстанційної системи судів [4, с. 1136]. Із системного аналізу ст.ст. 263 та 389 ЦПК випливає висновок, що правові позиції, викладені у Постановах Верховного Суду все ж є обов'язковими для застосування судами першої та апеляційної інстанції, оскільки незастосування зазначених позицій створює передумови для оскарження судового рішення в касаційному порядку. Варто зауважити, що водночас ці норми допускають можливість відступлення від цих позицій у виняткових випадках із відповідним належним обгрунтуванням та мотивуванням.

Як зауважує Ю.Ю. Рябченко, сутністю судового прецеденту можна вважати застосування норм права в конкретних обставинах, причому саме застосування норм права є змістовою частиною, а обставини є критерієм подібності наступних судових рішень [5, с. 97]. Якщо й говорити про ймовірність існування судового прецеденту в українському судочинстві та правозастосуванні, то лише з позицій доктрини «jurisprudence constante», яка, за словами Ю.Ю. Рябченка, охоплює інститут усталеної судової практики, який є інструментом правотворчості судів країн континентального права [5, с. 97]. «Вітчизняна судова практика, - веде далі науковець, - охоплюється поняттям «jurisprudence constante», що передбачає судове тлумачення норм права, яке не є обов'язковим, але набуває загальновживаності» [5, с. 97]. Лише із цієї позиції, на нашу думку, прецедент тлумачення можна ототожнювати з судовим прецедентом, при чому виключно в частині «ratio decidendi» - висновку суду з приводу правильного розуміння та застосування правової норми. Саме через наявність різних доктринальних підходів до поняття судового прецеденту в українській правовій системі доречніше вживати специфічний термін «прецедент тлумачення» і не застосовувати до правових позицій Верховного Суду термін «судовий прецедент». Варто звернути увагу на позицію професора В.В. Комарова, який наголошує на тому, що прецедент судового тлумачення, на відміну від судового прецеденту, не веде до створення судами норми права [6, с. 570]. Крім того, вчений вважає цілком допустимим називати рішення вищих інстанцій з конкретних справ прецедентами судового тлумачення правових норм, оскільки рішення судів, які мали бути зразком правильного застосування законодавства, 
через свою переконливість стають загальновідомими, сталими і враховуються в судовій діяльності [6, с. 570]. Отже, вважаємо доречним та допустимим застосування до правових позицій Верховного Суду терміну «прецедент тлумачення».

Оскільки законодавство не містить визначення поняття «джерело права», час від часу згадуючи про те, що саме можна вважати джерелом права, то можна говорити лише про доктринальні підходи до визначення цього поняття. Так, відповідно до ст. 10 ЦПК під назвою «Верховенство права та законодавство, відповідно до якого суд вирішує справи» джерелом права визнається, зокрема практика ЄСПЛ. У КАС передбачена стаття 7 під назвою «Джерела права, які застосовуються судом». ГПК містить подібну норму, але під назвою «Верховенство права та джерела права, що застосовуються судом». Ці статті містять вказівку на нормативно-правові акти як на джерела права, водночас уповноважуючи суд на застосування аналогії права або аналогію закону у разі неврегульованості певних спірних відносин, при цьому не визначаючи статус судової практики, яка складається в результаті такого застосування. Отже, поодинокі згадки в чинному законодавстві про «джерела права» та їх перелік дають можливість зробити висновок, що судову практику як результат тлумачення та роз'яснення правової норми, або як результат застосування норм, що регулюють подібні відносини, чи як результат застосування принципів права не можна розглядати в якості джерела права. Із цього приводу висловлюється Д.Д. Луспеник: «Незалежно від офіційного визнання судової практики в якості джерела права, вона реально породжує юридичні норми, долаючи наявні численні недоліки, прогалини чи суперечності в законодавстві, створюючи тим самим своєрідний канал правотворення і становлячись зворотньою реакцією на виникнення нових суспільних відносин, які пізніше офіційно втілюються в правові норми [1, с. 116]. О.С. Кізлова зазначає, що судова практика - це особливе джерело цивільного права; вона займає підлегле становище в структурі джерел цивільного права по відношенню до законодавчих актів: не повинна суперечити принципам, цілям і завданням законодавства, а також його змісту [7, с. 362]. Є.П. Вертегел і В.С. Посашкова у своїй статті приходять до висновків, що судова практика є джерелом права, що має свою специфіку, характеризується особливими ознаками та слугує важливим регулятором поведінки суб'єктів права; не варто плутати судову практику із судовим прецедентом; прецедент є одиничним, конкретним, а судова практика - це фактично результат узагальнення сукупності рішень в одноманітних справах [8, с. 27]. Л.Г. Лічман наводить таке визначення судової практики: судова практика - це вид юридичної практики, яка є досвідом правової діяльності компетентних суб'єктів, що формується в результаті застосування права при вирішенні юридичних справ [9, с. 35]. Ураховуючи викладені вище позиції, вважаємо, що терміни «прецедент тлумачення» та «усталена судова практика» є досить близькими за змістом, однак з тією різницею, що прецедент тлумачення є одним конкретним рішенням, у якому розкрито та роз'яснено зміст відповідної правової норми і яку слід застосовувати саме у тому сенсі, як розтлумачив Верховний Суд, а усталена судова практика охоплює сукупність подібних рішень, у яких застосовані правові норми з тим змістовним наповненням, якого їм надав Верховний Суд. 
Звісно, що будь-яка правозастосовча діяльність суду із застосування матеріальних норм до спірної ситуації є формуванням судової практики, але практики кожного конкретного суду і це зовсім не означає, що застосування тих самих норм буде мати тотожне втілення у судових рішеннях, якщо такі норми допускають хоча б мінімальну неоднозначність тлумачення. Саме тому варто розрізняти судову практику місцевих судів та апеляційних і судову практику Верховного Суду, які, маючи різний інстанційний статус, мають різне процесуальне значення для формування практики інших судів. У своєму дослідженні Т.А. Цувіна приходить до висновку, що ЄСПЛ не вимагає від держав-членів абсолютної єдності судової практики, допускаючи їі дивергенцію на рівні нижчих інстанцій, що визнається закономірним явищем, адже помилки судів нижчих інстанцій мають виправлятися судами вищих інстанцій [10, с. 66], відсутність єдності практики на рівні нижчих інстанцій не свідчить про порушення права на справедливий судовий розгляд, адже завданням судів вищих інстанцій якраз і є виправлення помилок у правозастосуванні судів нижчих інстанцій [10, с. 66]. А отже, усталеною судовою практикою можна вважати саме практику вищих судових інституцій, яким необхідно терміново реагувати на дивергенцію у рішеннях нижчих судів, у результаті діяльності яких найчастіше і виявляється неоднозначність правотлумачення. При цьому усталена судова практика не є результатом правозастосування у конкретній справі, а є результатом виявлення змісту правових норм через багаторазове однакове застосування тих самих норм, що знаходить своє втілення у правових позиціях, які майже перетворюються на норми права, але такими все ж не стають. Водночас, з терміном «судова правотворчість» варто бути досить обережним. Як зазначає І.П. Зеленко, продовжує викликати суперечності сумісність правотворчої функції судів з конституційним принципом поділу державної влади, а також залишаються недостатньо розглянуті процесуальні правила (які встановлюють послідовність здійснення правотворчих дій) та їх тривалість у часі (моменти їх початку та завершення) [11, с. 12].

Слід зауважити, що спірна ситуація без належного правового регулювання може виникнути перед судом будь-якої ланки, який змушений буде за відсутності правової позиції Верховного Суду самостійно усувати прогалини законодавства. Так, звісно, нову норму суд не створюватиме, він буде тлумачити сукупність правових норм, максимально наближених до регулювання спору, і його тлумачення буде відображенням його суддівського розсуду і реалізації дискреційних повноважень. Однак для інших судів тієї ж інстанції і тим паче для вищих судів його правова позиція не буде мати обов'язкового значення, саме через те, що в Україні судовий прецедент (у його класичному розумінні - як рішення, що є обов’язковим до застосування іншими судами при вирішенні аналогічних справ) не визнається джерелом права. Проте, як убачається, виявлення місцевими судами чи апеляційними судами, які виступають як суди першої інстанції, при вирішенні конкретної справи певної прогалини у законодавстві, має бути, з одного боку, сигналом для Верховного Суду для відповідного реагування у вигляді прийняття правової позиції зі спірного питання, а з іншого боку, сигналом для законодавчої гілки влади про необхідність усунення прогалини. Саме тому вважаємо за доцільне упов- 
новажити місцеві та апеляційні суди правом на подання запиту-звернення до Верховного Суду щодо правильного розуміння правової норми або щодо допустимості застосування аналогії закону (чи аналогії права), а ст. 251 ЦПК доповнити такою обов'язковою підставою для зупинення, як «подання запиту-повідомлення до Верховного Суду щодо тлумачення норм, які підлягають застосуванню». Якщо Верховний Суд викладе свою правову позицію щодо правильного розуміння правової норми ще під час перебування справи на розгляді у суді першої інстанції, це убезпечить Верховний Суд від звернення до нього в касаційному порядку завдяки викладеній у ст. 389 ЦПК системі касаційних фільтрів.

Актуальним в аспекті досліджуваного питання видається такий приклад. 19 квітня 2021 року у кримінальній справі № 336/7734/20 [12] Шевченківський районний суд м. Запоріжжя визнав електросамокат транспортним засобом, а цивільний позов щодо стягнення на користь потерпілої матеріальної та моральної шкоди задоволено. Це рішення є досить цікавим з різних точок зору. 3 одного боку, суд у своєму рішення однозначно висловився, що згідно з п. 1.10 Правил дорожнього руху електросамокат є транспортним засобом, оскільки підпадає під загальне визначення транспортного засобу, проте, на відміну від мопеда, велосипеда та інших транспортних засобів, визначення електросамокату у Правилах відсутнє. Водночас, з іншого боку, справедливість зазначеного висновку не викликає сумнівів, оскільки технічний прогрес, від зловживання здобутками якого і зазнала шкоди потерпіла особа, не знайшов свого відтворення у відповідних нормативних актах. Ця ситуація яскраво показує, що спірні правовідносини виникли, проте вони не мають чіткого правового регулювання в національній правовій системі. $\mathrm{y}$ даній ситуації суд змушений був розтлумачити норму i, використавши дискреційні повноваження, класифікувати електросамокат як транспортний засіб, водій якого порушив Правила дорожнього руху, що потягло спричинення тілесних ушкоджень. Якби суд цього не зробив, то відновлення порушеного права потерпілої було б під питанням. Отже, суд більш оперативно може відредагувати на відсутність відповідної правової норми, застосувавши певну норму за аналогією або розтлумачивши незрозумілу норму і висловивши свою позицію щодо спірних правовідносин. Безумовно, суддя суду першої інстанції проголошує свою особисту думку, керуючись дискреційними повноваженнями. Згадане рішення має стати каталізатором відповідних законодавчих змін, пришвидшити процес нормування діяльності новомодних пристроїв. Відповідний законопроект щодо використання електросамокатів на сьогодні вже пройшов перше читання у Верховній Раді. I доти, доки він буде остаточно прийнятий, може трапитися чимало подібних ситуацій, а відповідні суб'єкти права на захист потенційно можуть звернутися до суду за захистом своїх прав.

Таким чином, на підставі усього вищевикладеного можна стверджувати, що елементи прецедентного права де-факто стали частиною правової системи України, що підтверджується положеннями про те, що практика ЄСПЛ визнана джерелом права, а висновки щодо застосування відповідних норм права, викладені в постановах Верховного Суду, мають бути враховані судами при застосуванні норми права до спірних правовідносин. 
У площині національного законодавства доцільно говорити про існування специфічного різновиду судового прецеденту, а саме прецеденту тлумачення, який формується судами вищих інстанцій у вигляді певних правових позицій як результат усталеної судової практики. Про це свідчать такі положення:

1) під час роз'яснення змісту та сутності наявної правової норми або застосування аналогії у процесі ухвалення судового рішення нова норма права не створюється, однак надається iï тлумачення, і саме в наданій інтерпретації зазначена норма має застосовуватися в подібних правовідносинах судами усіх інстанцій;

2) у разі відсутності норми, яка прямо регулює спір, судова інституція застосовує до спірних правовідносин норму, яка має найбільш тісний зв'язок зі спірною ситуацією (за аналогією закону), або застосовує принципи права, коли до спірної ситуації не можна застосовувати навіть подібну, так звану «найближчу» норму (за аналогією права).

На наш погляд, у ЦПК варто закріпити положення про те, що суди нижчих інстанцій, виявивши в законодавстві прогалину або наявність розбіжностей у розумінні правової норми, повинні шляхом надсилання запиту повідомити про це Верховний Суд, який має надати офіційне тлумачення, що буде обов'язковим для застосування іншими судами (це так званий тимчасовий захід до заповнення відповідної прогалини законодавцем або внесення змін до наявних нормативно-правових актів з відповідним, більш точним формулюванням). Виявлена прогалина в подальшому потребує внесення змін до законодавства, а норми права мають бути сформульовані відповідно до висновків таким чином, щоб не допускалося якесь неоднозначне тлумачення. Крім того, у ст. 10 ЦПК варто закріпити, що прецедент тлумачення (правові позиції Верховного Суду) є джерелом права, з метою усунення сумнівів щодо його обов’язковості під час вирішення цивільно-правових спорів.

\section{Jimepamypa}

1. Проблеми теорії та практики цивільного судочинства : монографія / В. В. Комаров, В. І. Тертишніков, В. В. Баранкова та ін. ; за заг. ред. В. В. Комарова. Харків : Харків юридичний, 2008. 928 с.

2. Любчик О. А. Правовий прецедент - джерело права в Україні: так чи ні? Вісник ЛДУВС і.м. Е. О. Діәоренка. 2020. Вип. 3(91) С. 41-54.

3. Марченко А. А. Поняття судового прецеденту та його місце у правовій системі України. Митна справа. 2013. № 5. Ч. 2. Кн. 1. С. $26-32$.

4. Попов О.І. Принцип правової визначеності та його реалізація у цивільному судочинстві. Liber Amicorum Вячеслав Комаров / за ред. Т. В. Комарової ; упоряд. Т. В. Комарова. Харків : Право, 2020. С. 1127-1136 .

5. Рябченко Ю. Ю. Судовий прецедент і джерела цивільного процесуального права: проблеми та перспективи. Науковий вісник Міжнародного гуманітарного університету. Сер.: Юриспруденція. 2020. № 43. С. 96-98.

6. Комаров В. В. Верховний Суд та єдність судової практики. Liber Amicorum Вячеслав Комаров / за ред. Т. В. Комарової ; упоряд. Т. В. Комарова. Харків : Право, 2020. С. 564-581.

7. Кізлова О. С. Категорії «судовий прецедент» і «судова практика» в системі джерел цивільного права України. Право і суспільство. 2015. № 6. Ч. 3. С. 356-364.

8. Вертегел Є. П., Посашкова В. С. Судова практика як джерело права: теоретико-правове дослідження. Юридичний науковий електронний журнал. 2020. № 2. С. 24-27.

9. Лічман, Л. Г. Значення судової практики для правозастосування у цивільному судочинстві України. Вісник Верховного Суду України. 2011. № 6. С. 34-38.

10. Цувіна Т. А. Єдність судової практики як елемент правової визначеності: підхід Європейського суду з прав людини. Проблеми законності: зб. наук. $n p$. Харків : Нац. юрид. ун-т ім. Ярослава Мудрого, 2019. Вип. 146. С. 63-74. 
11. Зеленко І. П. Дискусійні питання судової правотворчості на черговому етапі судової реформи. Наукові записки. Серія: Право. Вип. 8. 2020. С. 9-13.

12. Рішення у справі № 336/7734/20 від 19 квітня 2021 p. URL: https://reyestr.court.gov.ua/ Review/96352078

\section{Анотація}

Колісник О. В. Прецедент тлумачення у практиці цивільного судочинства. - Стаття.

У статті досліджено питання судової правотворчості, а також впровадження в національне цивільне судочинство елементів прецедентного права. Визначено сутність прецеденту тлумачення, його співвідношення з судовим прецедентом та усталеною судовою практикою. У роботі наголошується на особливій ролі Верховного Суду у здійсненні правороз'яснювальної діяльності і формуванні правових позицій з метою забезпечення єдності правозастосовчої практики у контексті принципу правової визначеності. Зроблено висновки про те, що деякі елементи прецедентного права де-факто стали частиною правової системи України у формі прецеденту тлумачення як специфічного різновиду судового прецеденту, який формується судами вищих інстанцій у вигляді певних правових позицій як результат усталеної судової практики. Про існування прецеденту тлумачення у правових реаліях України свідчить те, що у результаті роз'яснення змісту правової норми або застосування аналогії у процесі ухвалення судового рішення нова норма права не створюється, однак надається її тлумачення. Саме в наданій інтерпретації зазначена норма має застосовуватися у подібних правовідносинах судами усіх інстанцій. Наголошується на особливій ролі місцевих та апеляційних судів у виявленні правових прогалин. У зв'язку із цим запропоновано надати право цим судам звертатися до Верховного Суду із запитом-повідомленням щодо офіційного тлумачення наявної правової норми або щодо правильності застосування аналогії права чи закону. Автором стверджується, що усталена судова практика охоплює сукупність подібних рішень, у яких застосовані правові норми з тим змістовним наповненням, якого їм надав Верховний Суд, а прецедент тлумачення є одним конкретним рішенням, у якому розкрито та роз'яснено зміст відповідної правової норми і яку слід застосовувати саме у тому сенсі, як її розтлумачив Верховний Суд. Отже, відповідні правові позиції, а саме прецедент тлумачення, варто розглядати як результат усталеної судової практики. Визнається доцільним у ст. 10 ЦПК надати прецеденту тлумачення статус джерела права.

Ключові слова: правові позиції, Верховний Суд, судовий прецедент, прецедент тлумачення, усталена судова практика, судова правотворчість, аналогія права.

\section{Summary}

Kolisnyk O. V. An interpretation precedent in the practice of civil proceedings. - Article.

The issues of judicial lawmaking as well as the implementation of the case law elements in the national civil proceedings are considered in the article. The essence of an interpretation precedent, its correlation to the judicial precedent and established judicial practice are defined. The work focuses on a special role of the Supreme Court in the legal explanatory activity and new legal positions formation to provide the law usage unity in the context of legal certainty. The author has come to the conclusion that de facto certain case law elements have already become part of the Ukrainian judicial system in the form of an interpretation precedent as a specific type of judicial precedent formed by the courts of higher instances in the form of certain legal positions as a result of established case law. The existence of an interpretation precedent in the legal realias of Ukraine is evidenced by the fact that a legal norm content clarification or using analogy in the process of adjudication do not lead to a new legal norm formation, however, its interpretation is given. And it is this norm interpretation that has to be applied by the courts of all instances. To identify the law gaps the local courts and courts of appeal are to play a special role. In this connection they are suggested to receive the right to apply to the Supreme Court for the request to interpret officially an existing law norm or clarify the correctness of an applied legal analogy or law. The author claims that the established judicial practice comprises a number of similar adjudications based on legal norms with the content provided by the Supreme Court. An interpretation precedent is one specific adjudication in which a relevant legal norm content is justified and clarified and which is to be applied exactly in the sense interpreted by the Supreme Court. Therefore, the relevant legal positions, namely an interpretation precedent, should be considered as a result of established judicial practice. It is recommended in Art. 10 of the CPC to give an interpretation precedent the status of a source of law.

Key words: legal positions, the Supreme Court, judicial precedent, interpretation precedent, established judicial practice, judicial lawmaking, analogy of law. 